\title{
From silence to solidarity: Locating the absent 'child voice' in the struggle against benefit sanctions
}

\author{
Lucy Benson and Rachel Rosen
}

\section{In press, Children \& Society}

\begin{abstract}
This article interrogates childhood politics through a case study of voluntary sector responses to benefit sanctions in the UK. The paper explores the absent 'voices' of children in this resistance and considers, in contrast, the possibilities of engaging with children's perspectives in political endeavours. We argue for the importance of moving away from both simple platitudes about listening to 'the voice of the child' and the 'political retreatism' (Alcoff 2009) that results from a sole focus on the impossibilities of representation. Whilst aware of inevitable power relations between children and adults, we suggest 'solidarity' as an animating concept, emphasising attention to the processes whereby people are differently impoverished.
\end{abstract}

Key words: voice, benefits sanctions, poverty, solidarity, childhood, generation

The UK government's 2012 reform of the 'benefit sanctions' system levelled penalties against people receiving social welfare support for apparent non-compliance and was met with wide-spread and vociferous resistance. Community organisations, activists and charities protested the intensification of sanctions in a series of reports which condemned the measures as 'a system that is disproportionately punitive towards those who already have the most difficult lives' (Joint Public Issues Team 2015, 25).

Across responses made by oppositional groups, children are repeatedly mentioned and the impact of the sanctions on impoverished children are raised. Yet, as we go on to discuss, the voices of real children are notably absent from the critique and resistance to sanctions. Why weren't children's 'voices' mobilised in the reports, particularly when including the voices of impoverished people was so central to their representational strategy? Why were children's 
own articulations about the impact of impoverishment absent from these deliberations, despite an increasing global rhetoric of 'listening to children'? And, more broadly, why is 'child poverty' seen as a site for intervention but rarely viewed as a unique position of information and vantage? This final question is particularly salient in the case of benefit sanctions, as we go on to discuss.

These questions raise the thorny issues of 'voice' and a politics of representation. On the one hand, rising attention to the political agency of children (Kallio and Häkli 2011) and commitment to UNCRC participation rights offers a series of normative claims and empirical evidence to support children's presence in the political realm (Ridge 2013). On the other hand, concerns have been raised that 'children's voices' are easily ventriloquised (Ruddick 2007) and used antagonistically against adults in their lives (Gillies 2014), or that children may be exploited in a politics of representation (Alcoff 2009; James 2007). Yet, these debates run the risk of leading those committed to social and economic justice into untenable or immobilising political positions.

In what follows, we explore the ways that 'voice' is used tactically by advocacy groups in their efforts to counter benefit sanctions, highlighting the place of 'the child' within this approach. The second part of the paper considers the implications of seeking to engage with children's perspectives in such political endeavours. In the final section, we propose and develop the concept of solidarity, as an alternative to voice and representation. We suggest that collective agency can emerge out of intergenerational dialogue about the concrete processes which impoverish, subjugate, and marginalise, as well as those which connect us.

\section{Austerity and sanctions in the UK context}

In 2008 the UK was thrown into an economic crisis activated by a huge trend of 'defaults on "subprime" mortgages in the United States' (Dowling and Harvie 2014, 873). To prop up the 'neoliberal deal', UK banks were released from responsibilities to repay their bills, instead the county as a whole paid. The national debt accumulated through these actions was enormous, with $25-40 \%$ of the country's debt 'a direct result of the bank bailout' (Dowling and Harvie 2014, 875). Meanwhile, 3.9 million children in the UK were living in relative poverty (after housing costs) in 2014-2015 according to the Department for Work and Pensions (DWP). In the UK, a key strategy of the state for addressing its sovereign debt crisis and the 'global economic slump' (McNally 2010) more broadly was to implement a swathe of cuts to welfare and public services. Describing this austerity approach in a speech in February 2011 Prime Minister David Cameron told the audience, 'It brings the most ambitious, fundamental and radical changes to the welfare system since it began.' 
One such 'radical change' was the reform of benefit sanctions. Sanctions came into being during Margret Thatcher's welfare reforms of the 1980's. The practice intensified in 2012 when new rules were introduced. The average number of sanctions applied 'has risen dramatically from 35,500 a month up to October 2012, to 84,800 after this date' (Beatty et al. $2015,9)$. Under the new measures, strict monitoring regimes have been set up by the DWP for those who are unemployed and receiving Job Seekers Allowance (JSE) or Employment Support Allowance (ESA). As part of a programme to demonstrate that they are making adequate searches for work, claimants are required to make a contract with the DWP of agreed targets for the numbers of job applications to be made, plus further requirements including attendance at trainings and meetings. If claimants are not compliant with agreed targets their benefits can be 'sanctioned' and their welfare payments will be stopped for 4 weeks on a first fault and 13 weeks for further transgressions.

Thousands of claimants who are responsible for dependent children have had these sanctions imposed, which leaves their households with extremely reduced incomes. Indeed, a charity report has shown that approximately 100,000 children were affected by sanctions in the financial year 2013/2014 (Joint Public Issues Team 2015). Children in the UK spend most of their time in schools where their work is not considered to be the kind of labour that should earn financial rewards (Qvortrup 1995). This, along with a construction of children which accepts that they should be protected from the work place and the market where they are considered to be vulnerable to exploitation (Nieuwenhuys 2011), means that children in the UK have little access to money of their own. They therefore depend upon the financial capabilities of their adult family members for the essentials of food, clothing and shelter (Olk 2011). Post-war Keynesianism had it that if adult kin were unable to provide these essentials, the state would provide assistance. In the case of benefit sanctions, the state has effectively withdrawn the welfare resources that make these provisions possible to punish the contract-breaking adults, and in this process children also suffer.

\section{'Child poverty'}

Benefits sanctions affect people already living on a low-income and the voluntary sector reports we go on to discuss frame much of their response in terms of poverty, including that experienced by children. In the last fifteen years, there has been rising state-level attention to the causes, measurement, and even alleviation of 'child poverty', as well as growth in research exploring children's subjective understandings and experiences of impoverishment. Indeed, an impressive body of academic and grey literature has emerged around the notion of 'listening to children's voices' about poverty (for meta-reviews see e.g. Crivello, Camfield, and Porter 2010; Ridge 2009; Attree 2006; Ridge 2011). 
This literature highlights that in addition to the economic constraints of living in poverty, including the challenge of having inadequate material resources for food, housing, education and transportation, the experience of impoverishment is profoundly social in nature. Children note that poverty can limit interactions with friends (Holloway and Pimlott-Wilson 2014), because of the cost of activities but also limits on safe places to gather given geographies of poverty and 'architectural injustice' (Farthing 2016, 112), and cause tensions within families (Walker, Crawford, and Taylor 2008). Children's accounts of poverty stress that it is highly stigmatising, leading to feelings of shame and social marginalisation, such as labelling for receiving free school meals (a proxy for poverty in the UK). Another theme in this literature is children's active role in mediating the impact of impoverishment, through their contributions to the household economy; limiting their needs; and developing extensive support networks (Ridge 2011; Dearden and Becker 2005).

Children's perspectives on poverty have potentially significant implications for social policy (Crivello, Camfield, and Porter 2010; Ridge 2009). Indeed, children have been involved in policy engagement and activism about poverty, such as the 2014 Children's Commission on Poverty organised by the Children's Society. Whether children's 'voices' do impact on either policy or wider public discourses is a question that we will set aside for now except to note that there is every indication that they have had only limited impact at best (Farthing 2016) particularly in a climate of retrenchment of funding streams to support children's participation in policy making and professional change (Nolas 2015).

\section{'Child voice' and impoverishment}

For the purposes of this article, we will focus on three salient critiques of approaches which attempt to 'captur[e] and represent the authentic voice of children in poverty' (Roets, Roose, and Bouverne-De Bie 2013, 538). The first of these critiques is that this neglects the contexts producing such voices, and instead presents children's voices as 'facts', where their articulations can be viewed as representing the essence of being poor. The point is methodological: the sites and ways in which impoverished children are asked about their experiences will shape their responses. At the same time this is an ontological claim: hopes, dreams, desires, and fears are always already social, shaped in dynamic ways by material, social and cultural relations. All articulations, as Bakhtin (1986) phrases it, are 'doublevoiced': containing both the near and distant context which precedes them as well as anticipations of the future.

A second critique focuses on the status of the speaking subject. Here, Ruddick (2007) argues that the child is an 'impossible subject'. Unable to signify her/himself in the liberal 
terms of representation and rational deliberation: not able to 'legally speak for him or herself' (Ruddick 2007, 516) and neither fully autonomous nor dis-embedded, the elocutions of the child subject remain under the authority of adults. The debate then becomes who is in the superior position to represent the child's voice. Regardless of which adult does so, children's voices remain mediated, translated (see, for example, James 2007; Spyrou 2011), and even 'ventriloquised' or filled with the interests and desires of the adult interlocutor (Ruddick 2007).

Given the complexities of voice, concerns arise that representing another is fundamentally an act of violence and oppression (Alcoff 2009). Despite all good intentions, in speaking for another, , the act of representation involves - to a degree at least - the imposition of a privileged interpretation. For our purposes, an adult's analysis may be foisted on to 'the child'. Perhaps even more fundamentally, relations of domination are buttressed rather than dismantled; 'the adult' remains the competent political representative and 'the child' remains the one who is spoken for.

For those concerned with social and economic justice, including challenging the subordination of those positioned as children, the implications of this deconstruction of the 'voice of the child' have led to efforts to rethink 'the political'. Here, political agency is reconceptualised in ways that make it independent of the ability to verbalise and make rational articulations. Embodied and non-representational modes are viewed as potentially deeply political (Rosen 2015). This also involves calls to reshape sites, spaces, and relations so that children's enactments can be heard and counted as political interjections in the world (Oswell 2009).

We see the rewriting of boundaries of 'the political' as a long-term project which needs to accompany, rather than supplant, efforts to engage with pressing and immediate issues such as benefits sanctions. The concern here is twofold: without rendering children's 'voices' meaningful they may be lost to public debate and focusing on the ambiguity and social production of 'voice' can relativize demands, rendering them politically impotent. In what follows, we pick up on these debates, considering both the absence of the 'voice of the child' in oppositional groups' responses to benefit sanctions as well as the political implications of including such voices.

\section{Responses to benefit sanction reforms}

To assess children's participation in the political landscape surrounding sanctions reforms, we completed an extensive internet search looking for publicly available responses. For the purposes of this article, our analysis focuses on 38 documents (hereafter 'reports') collated 
on the Child Poverty Action Group (CPAG) website. The vast majority of responses to a call for evidence for a 2013-4 DWP commissioned review of benefits sanctions can be found here, as well as reports written following the review. The 'Oakley Review' was led by Matthew Oakley, who at the time was a member of the Social Security Advisory Committee and is now part of the right wing 'Policy Exchange' think tank. One report comes from local government, one from academia written by Dr David Webster, and the rest from voluntary sector organisations. These include large international and national charities, medium sized and small community organisations and Citizen's Advice Bureaus. Their beneficiaries are include the homeless, women, adults with mental health issues, and lone parents.

We began by counting the number of times that the word child (and its derivations children and childcare) was used in each of the reports. In nine, 'child' was used more than once, but here we focus on the four reports where 'child' appeared most frequently. The report in which 'child' was most prevalent was the Fawcett Society's 100-page 'Where's the Benefit?' (WtB) from 2015 which addressed multiple issues surrounding the effects of sanctions on women, particularly focusing on 'undermining equality between women and men' (14). It raised issues concerning the wider programme of cuts, health and wellbeing and impacts on various groups including children. The next was the twelve-page 'Independent review of Jobseeker's Allowance sanctions response to call for evidence by the Single Parent Action Network' (SPAN) which included case studies from sanctioned parents. Gingerbread's (GB) ten-page report 'Single parents and Benefit Sanctions' had a similar format to SPAN's report and also responded to Oakley's Review. The final report used in our sample was the twentysix page 'Time to Rethink Benefit Sanctions' (TtRBS) a 2015 collaboration between several churches, which applied a Christian doctrine to question the morality of sanctions.

Once the four documents were selected, we considered the ways in which the word 'child' was invoked. We attended to the types of spaces and activities which children were associated and the sets of relationships in which children appeared. Overall, we considered what this had to say about constructions of 'the child'. Children were most frequently associated with compulsory education in the reports: 'Caller $\mathrm{H}$ was told by her Work Programme adviser that all her benefits would be stopped if she doesn't go to see him at $4 \mathrm{pm}$; this is the time she picks up her child from school' (GB: 5). This statement echoes numerous other statements throughout the reports and encourages a view of children as contained by compulsory spaces, rather than considering the more social and chosen aspects which hold great importance for children (Corsaro, 2011).

The word child was frequently deployed to present children as objects of care, fundamentally dependent on parents, but more specifically mothers. The term 'caring responsibilities' for 
children was used 30 times in WtB, and there were also numerous references to childcare (GB, TtRBS, SPAN). Childcare is a professional term that has been subsumed into everyday discourse (Langford et al, 2014), influencing perceptions of children as in need of constant care and supervision. This usage reinforces the idea of children as vulnerable dependants, a paradigm that is so entrenched in collective thinking that it is considered a natural state for children rather than a societal construct (Woodhead, 2011). This stance fails to recognise the contributions of many children to their families' survival through the forming of supportive relationships outside of parental ties in order to survive situations of poverty (Hall 2015).

This 'natural' vulnerability and need for supervision is presented in the reports as a hindrance to adults' possibility of representing themselves to the state: 'We've got children hanging off us so we haven't got time to be arguing with these people' (WtB: 67). Children are further projected as a parental burden, impeding adults' ability to comply with sanctions contracts: 'Another parent was given an appointment that clashed with school drop off. When she tried to change the appointment she was told she must attend or lose her benefit' (SPAN: 6). They were also presented as barriers to parents' ability to work, illustrated by a case study of a parent who had to give up full time work to care for her autistic son (WtB: 55). Yet conflicts that appear to be between parents/mothers and children are often about something entirely different. Here, the 'burden' of children reflects the privatisation of both childhood and responsibility for social reproductive labour.

In TtRBS, mothers and children are conflated into a single object, 'womenandchildren' (Enloe 1991), presented as victims in need of saving. "Defend the orphan, plead for the widow". Isaiah $1: 17 \ldots$ These were the people least able to defend their own rights and to seek justice for themselves.' (TtRBS: 8 ). This child saving stance is common in charitable organisations' representations of children (Wells 2009) and, through their association, mothers.

The second area we considered in the reports relates to the question of 'voice'. Here we considered whose 'voices' were included, how they were represented, and what purposes they served in the text. The 'voices' of people experiencing sanctions were gathered in a variety of ways: qualitative interviews with JSA claimants $(\mathrm{WtB})$, regional focus groups (WtB), contributions to an online forum (SPAN), written submissions in response to organisational requests (WtB; TtRBS) and information gathered from a telephone helpline (GB). 
The 'voices' of the benefits claimants used throughout the reports were a means of adding legitimacy, in their expressions of the everyday business of living in poverty: 'Go home in the afternoon, get a few hours sleep, get up and do my caring responsibilities, then get a few more hours sleep and get up and go back. And I thought, are you really taking the $\mathrm{p}^{* * *}$ now? Because I don't want to put myself in an early grave' (WtB: 44). Parents', especially mothers', voices were prevalent and highlighted their restraint as well as their responsibilities to protect 'blameless' children: 'Sometimes I go without food just to feed my kids. Because you do for your children' (WtB: 63). For over a decade there has been an establishment discourse, straddling New Labour and Conservative leaderships, which places blame for child poverty and its impacts on disadvantaged families (Gilles, 2014). The use of parents' voices in the reports counteracts these assumptions by presenting the sacrifices of suffering families and creates sympathy by shifting the blame from the individual to the structure of society.

Voices also served as evidence for the organisation's critique of the benefit sanctions system. For instance, in all 4 reports claimants highlighted practises of unclear communication: 'I was given the wrong form to fill in on several occasions. Various forms were so difficult to fill in that I had to get help from family and friends to do it' (WtB: 36). They added texture by emphasising the humiliating nature of claimant's experiences (WtB, SPAN, TtRBS). Claimants spoke of being 'abused', 'maltreated', 'depressed', 'worthless', 'disrespected', and 'downtrodden'. (WtB: 74). Voices were also crucial to the emotional persuasiveness of the reports: 'They crush you. I found the experience at the Jobcentre Plus so awful l'd rather starve than go back there again' (TtRBS: 20). Together, these expressions aid the reader in experiencing the sanctioned adult as 'fully human' (Freire, 1996). Finally, voices were deployed as a call to action in TtRBS: 'People are getting pushed to the limit. They are sick with the stress. It really hurts the bones on us. But we refuse to be victims... join us in demanding change' (5).

Although children appear to be the motivation for several recommendations in the reports, including the call to suspend sanctions for families with children, their voices were completely absent from all reports. Here, it is also worth noting that CPAG was the only child-focused organisation amongst the 38 included on their website, and the only mention of 'child' was in their charity's name. The effects that children are suffering because of sanctions are only alluded to through the comments of adults. Children are positioned alongside those who live with the impacts benefits sanctions but are notafforded the right to speak. This silence, and its political ramifications, presents us with an absence which we now move on to analyse. 


\section{The absence of children's voices}

In contrast to the growing focus on listening to children about poverty more generally, why weren't impoverished children seen as relevant informants in relation to benefits sanctions? One possible explanation for the absence of children's voices in the reports is that many adults believe that children should not be troubled with macro-level problems; they should instead, this line of thinking goes, be allowed a life of innocence and play. As children's direct economic contributions to their families has been decreasing steadily since the end of the nineteenth century, particularly in advanced capitalist countries like the UK, their value has been reconstructed as 'emotionally priceless', of great sentimental value (Zelizer 1994). This conceptualisation of 'the child' is now deeply entrenched, with many believing that childhood should be a time free from responsibility shielded from involvement in problems of society (Hart 1992). Even efforts aimed at 'listening to children' tend to focus on highly localised and normatively-constructed concerns of childhood, such as the more 'private' sphere of the family, school or play spaces rather than issues such as benefit sanctions which are linked to normatively-constructed 'adult' concerns of work and the political economy (Hart 2008).

Children whose experiences do not conform to idealised models of middle-class Western childhood are often presented in the highly emotive terms of surviving 'lost' or 'stolen' childhoods. One mother in the SPAN report represents her son as living in a bubble: 'He loves his life. I would never burst his bubble but I am on a work programme and under the threat of a sanction' (6). As such, organisations compiling the reports may have worried about upsetting or otherwise violating the 'sacred' space of childhood by asking children to speak about the impact of sanctions. However, if 100,000 children's lived experiences are reduced to that of hunger, deprivation and anxiety as the TtRBS report implies, then it cannot be argued that they are being protected from political economic issues. Their everyday experiences are coloured by the consequences of political decisions considered too adult for their reckoning.

A second plausible explanation for the absence of children's voices is a dominant perspective that children do not, indeed cannot, have anything worthwhile to contribute to discussions of policy and political economy, including the sanctions reforms and their effects. There are several reasons for this stance. Firstly, children are not seen as complete beings. They are instead perceived as being in a state of becoming, hence their opinions are considered unready for the adult domain, as they are seen as not yet capable of making 
meaningful, completely formed assessments required of rational (neo)liberal political subjects (Ruddick 2007). Secondly, children are seen as in need of protection, even from their own decisions and opinions, lest they experience regrets in the future, harm themselves in the present or make naive choices (Brown Rosier 2011). Thirdly, those in more powerful positions have an investment in the status quo and a shift in the status of one marginalised social group, in this case impoverished children, would create a threat for systems which are considered natural and which serve existing elites (Freire 1996).

In following through on the point that children are an oppressed or marginalised social group (Liebel 2014; Ansell 2014), we locate another possible explanation for the absence of children's voices. Adult notions, constructs and voices are dominant in a society where we do not hear from children. In many ways the recognition of an absence confirms the dominance of a presence (Collier 2001). In highlighting this absence, adult domination becomes both noticeable and vulnerable. If children's voices are sought in public debates then children as a social group will be repositioned as having political, and not just emotional, value and not just as future citizens. The shift would fracture the hegemonic construction of childhood as 'human becoming' and adulthood as the 'gold standard' of development. Childhood would no longer suffice as a site for containment for hopes and dreams of the future (Zelizer 1994), nor could the dominion of adults over children continue to be taken-for-granted. This loss could be emotionally troubling for adults in its shift away from what seems 'fixed and static' (Alderson 2012, 190). In accepting children as qualified to speak about the effects of benefit sanctions, British publics more broadly would have to admit that childhood in the UK is not a 'bubble' of protection and comfort. The absence being articulated here is painful, as sentimentalised constructs of childhood are exposed as fictions, having little meaning for thousands of UK children. We do not suggest here that these troubles are necessarily articulated or even knowable for the adults involved in putting together the reports contesting benefits sanctions. However, deep-seated attachments to normative constructions and positions of (generational) privilege can often shape political strategies and everyday relations in ways which buttress inequitable social relations or silence the already marginalised (Mohanty 2003).

The recognition of the absence of children's voices, however, reveals an ill which itself needs to be absented (Collier 2001). This recognition could announce the beginning of change; here we consider the possibility of children's political doings and voicings informing responses to benefit sanctions. 


\section{The presence of children's voices: Implications, worries, concerns}

As we have noted, the four reports present the voices of adults affected by benefits sanctions as forms of evidence, to achieve legitimacy, and as a call to action. Whilst they certainly recognise that impoverished children are affected by benefit sanctions, they do not mobilise children's voices for the possible reasons which we outline above. This can have a negative impact on children and the status of childhood, but it also can be viewed as a missed opportunity. The figure of the child in political campaigns is noteworthy for its symbolic power to catalyse adult action (Dubinsky 2012). Indeed, it is possible that children's own voices could be very effective in creating emotional and moral responses amongst broader publics. However, several difficulties arise when considering how children's voices could be integrated into reports such as these, some of which we have already gestured to above in relation to the problems of seeking the 'authentic voice' of impoverished children.

The first problem is bound up with power within adult-child relations and questions about who selects, interprets, and represents 'voices' and the basis on which these decisions are made. Should organisations select 'voices' to represent different views on benefit sanctions or those which forward the claims of the organisation or based on some other criteria? Is the priority on reflecting the mode and language of the child speaker or in making translations, so that articulations are recognisable to broader publics? Freire $(1996,42)$ raises the difficulties more powerfully positioned people encounter in making representations given negative social constructions, in this case of the dependent, non-speaking child: 'They almost always bring with them their origin: their prejudices and their deformations, which include a lack of confidence in the people's ability to think, to want and to know.' It is impossible to avoid power relations between children and adults, given their differential positioning. Both the powerfully positioned adult and the child speaker will internalise and embody hierarchical relations, affecting the possibilities for communication and representation. Indeed challenging generational power in research and advocacy are central concerns in the childhood literature, with Larkins and colleagues $(2015,357)$ arguing that 
this requires a shift away from child voice and standpoint to one of 'intergenerational dialogue in a communicative space'.

A second, and related point, relates to the diversity of individual children, not least because of how their lives are 'raced' and gendered, but also across childhoods. As such, one child cannot be used to represent all children (Woodhead 2011) and one voice can never represent a singular 'voice of the child'. These representational decisions are complex, but in the case of generational interactions typically remain the hands of adults (James 2007, 265). While there are other worries associated with including children's 'voices', a final concern we point to here relates to the problems of a 'politics of pity'. Drawing on Boltanski, Wells (2009) argues that images of children, and here we add children's voices, are very often projected to arouse emotional reactions that dominate over an intellectual response. Thus, they sidetrack questions about the processes that cause poverty. A 'politics of pity' is in line with a child saving position rather than an emancipatory approach to politics. Whilst representing children's suffering may well lead to readers taking action such as giving to foodbanks or supporting charities, it may stop them from asking difficult questions of the state.

These critiques of the absence and presence of children's voices, however important, do little to answer practical questions about political tactics, questions made even more urgent in the context of entrenching austerity and deepening inequalities. It is to these questions that we move in the final section.

\section{Towards a framework of solidarity}

As we have outlined, much of the critique of 'voice' pivots on the power relations in which voices are produced, mediated and represented. However, in this final section, we argue that emphasising the impossibility of speaking for the Other is politically detrimental. It can reify socially-produced distinctions between those positioned as 'adults' and 'children' as though their division were natural. It can reduce children to a pre-social state, separating them from communities they are embedded within. Such reifications preclude collective struggle. Yet, if we accept that such relations are socially constituted then they can also be 
unmade or, perhaps more precisely, made differently. Building common cause is both possible, even essential, we argue, for challenging the draconian impact of benefit sanctions as well as social and economic injustices more broadly, given the remarkable durability and intensification of global capitalism and its attendant inequities (Mohanty 2003).

Here, we move away from debates over the (im)possibilities of adequately representing children's voices to suggest another way of approaching this political problem. We suggest that the concept of solidarity has considerable intellectual and political purchase for reframing the dilemmas of 'voice'. Solidarity premises mutuality and interdependence, rather than autonomy. As we use it here, solidarity references a provisional unity between interlocutors formed through political struggle which can motivate and guide action (Scholz 2015). - Solidarity has been critiqued for being: premised on false universalisms or relations of saviour-vulnerable victim; conditional and easily withdrawn; and mobilised in the interests of capital or various state actors (e.g. see Chandra and Toor 2014). Yet, we are compelled by feminist and de-colonialist efforts to hold on to solidarity and, in the process, refine its meaning and practice. In what follows, we invoke solidarity as it has been developed within these traditions and offer some preliminary suggestions as to how this can help in reorienting intergenerational politics.

Interdependence is central to solidarity. Instead of viewing 'children' and 'adults' as separate and antagonistic, solidarity implies an ethical and political responsibility to 'mobilize for the welfare of other members and of the community as a whole' (Chandra and Toor 2014, 16). Rather than viewing 'community' as a reflection of a common identity, this is a recognition that people are interconnected but 'unequally enmeshed' in relations of domination (Siddiqi 2014 , 301). Commonality here is not based on pre-determined social, cultural, geographic, or kinship categories but is forged through efforts to sustain and make worthwhile everyday life, as well as engage in common struggles against forces which threaten such existence (Mohanty 2003). This moves away from questions about who can or should represent children's voices towards questions of how we, adults and children, might engage together in responding to injustices.

In what follows, we flag up four points for consideration in developing a notion of intergenerational solidarity. First, this implies recognising children's political subjectivity and potential participation in political struggle. This necessitates interrogating the ways in which spaces associated with community organising may exclude children (see, for example, Rosen, Baustad, and Edwards in press, for a discussion of the ambivalent position of children in women's organisations). This also means reorienting ideas about the breadth of 
issues which are of concern to children and the sites and activities which we can imagine as potential political spaces for forging common struggles.

Second, with Alcoff (2009), we stress dialogic engagements as central to solidarity: an effort of speaking with rather than for others. Taking a dialogic approach, whilst continually interrogating power relations, can allow for more situated knowledges to be expressed about the impact of benefits sanctions and other important social issues. We can gain a better understanding of benefit sanctions and neoliberal austerity more generally through attention to the ways it operates on the different social groups that people are positioned within, and can build more effective repertoires of action by critiquing 'solutions' which may leave unchallenged, or even exacerbate, the oppression of others. Such dialogue necessarily needs to consider a variety of modes of expression and engagement, including verbal, embodied, affective, and other non-linguistic registers. Equally, it means accepting that children may not want to engage.

While prioritising dialogue and fully aware that speaking for the other is never politically neutral, Alcoff (2009) argues that anxieties of misrepresenting others should not hold individuals back from attempts at speaking out. Refraining from doing so, she suggests, is a form of privileged political retreatism and silent individualism that can perpetuate injustices. To this we would add that the framework of solidarity we are building on here suggests that any act of 'speaking for' another should be grounded - as much as possible - on dialogue about the varying impacts of injustices, people's diverse interests, and the most politically strategic ways to ensure these are met. In other words, this framework moves away from 'who is the best representative' to 'what can we do together to make world more just?' In such a process, 'voices' are not just implicitly 'double-voiced' but they are self-consciously made collective and subject to sustained contestation. Such dialogue may include the temporary decision that having an adult 'spokesperson' would be the best way to have collective concerns heard. This representative role should be uneasy however, the subject of continuing interrogation of the privileged speaking position and the impacts of the act of representing others (Alcoff 2009).

Third, solidarity can challenge essentialist representations of 'child poverty', embodied in the 'voice of "the poor child"' (Roets, Roose, and Bouverne-De Bie 2013, 540). A person is not a 'poor child' but is made into one both through processes of generationing and those of dispossession, indebtedness, and private appropriation (Federici 2014). Further, to speak of 'child poverty' not only serves to separate children from the adults in their communities but a simple word substitution (e.g. 'adult poverty') demonstrates the emotive force of the term which both evokes a blameless child in need of saving while the culpable adult is an 
'impossible subject' of solidarity. In contrast, a focus on 'common differences' (Mohanty 2003) encourages attention to the processes which impoverish. By investigating processes which interconnect people in common differences we can see how benefit sanctions and other technologies of neoliberal austerity have differential effects. Collective agency, we argue, can emerge out of this intergenerational dialogue.

Finally, attending to impoverished and marginalised childhoods is one place to begin dialogue. If political action is based on the concerns of more privileged groups, it is likely it will wind up reproducing relations of domination (Mohanty 2003). Children's experiences of benefits sanctions, austerity measures, and varying oppositional strategies can be telling considering their oppression and subjugation. Given their traditional exclusion from 'the political', children, like other 'outsiders' (Scholz 2015, 395), may have much to offer to efforts of imagining new ways of being and living.

\section{Conclusion}

In this article, we highlighted the absence of children's voices in the political realm, through investigation of oppositional groups' responses to the UK government's intensification of benefits sanctions. We went on to explore what would happen if children's voices were included, stressing concerns about translations of 'children's voices' by adults. In response, we called for solidarity: a turn toward the 'Other', and toward 'community', to consider how the situations we find ourselves in are connected. We argued that this attention to common differences allows a fundamentally different starting point to individualistic notions of voice, provided that continual attention is paid to power relations. Solidarity prompts consideration of how we might form communities across differences of generation, and otherwise, to work together for social and economic justice.

\section{References}

Alcoff, LM. 2009. The Problem of Speaking for Others. In Voice in qualitative inquiry: Challenging conventional, interpretive, and critical conceptions in qualitative research, edited by A. Y. Jackson and L. A. Mazzei. Oxon: Routledge.

Alderson, P. 2012. Young children's human rights: A sociological analysis. International Journal of Children's Rights 20:177-198.

Ansell, N. 2014. The Convention on the Rights of the Child: Advancing social justice for African children? In Children's Lives in an Era of Children's Rights: The progress of the Convention on the Rights of the Child in Africa, edited by Afua Twum-Danso Imoh and N. Ansell. London: Routledge. 
Attree, P. 2006. The social costs of child poverty: a systematic review of the qualitative evidence. Children \& Society.

Bakhtin, M. 1986. Speech Genres and Other Late Essays. 1st ed. Austin: University of Texas Press.

Beatty, C, M Foden, M Lindsey, and K Reeve. 2015. Benefit Sanctions and Homelessness: A scoping report. London: Crisis.

Brown Rosier, K. 2011. Children as Problems, Problems of Children. In The Palgrave Handbook of Childhood Studies, edited by J. Qvortrup, W. Corsaro and M.-S. Honig. Basingstoke, Hampshire: Palgrave Macmillan.

Chandra, S, and S Toor. 2014. Introduction [special issue on solidarity]. Women's Studies Quarterly $42(3-4): 14-24$.

Collier, A. 2001. On real and nominal absences. In After postmodernism: An introduction to critical realism, edited by J. Lopez and G. Potter. London: Athlone.

Crivello, G, L Camfield, and C Porter. 2010. Researching Children's Understandings of Poverty and Risk in Diverse Contexts. Children \& Society 24 (4):255-260.

Dearden, C, and S Becker. 2005. Growing up caring: young carers and vulnerability to social exclusion. In Youth Policy and Social Inclusion: Critical Debates with Young People, edited by M. Barry. London: Routledge.

Dowling, E, and D Harvie. 2014. Harnessing the Social: State, Crisis and (Big) Society. Sociology 48 (5):869-886.

Dubinsky, K. 2012. Children, Ideology, and Iconography: How Babies Rule the World. The Journal of the History of Childhood and Youth 5 (1):5-13.

Enloe, C. 1991. Womenandchildren: Propaganda Tools of Patriarchy. In Mobilizing Democracy: Changing The U.S. Role in the Middle East, edited by G. Bates. Monroe, ME: Common Courage Press.

Farthing, R. 2016. What's Wrong with Being Poor? The Problems of Poverty, as Young People Describe them. Children \& Society 30 (2):107-119.

Federici, S. 2014. From Commoning to Debt: Financialization, Microcredit, and the Changing Architecture of Capital Accumulation. South Atlantic Quarterly 113 (2):231-244.

Freire, P. 1996. Pedagogy of the opressed. London: Penguin.

Gillies, V. 2014. Troubling Families: Parenting and the Politics of Early Intervention. In Thatcher's grandchildren? : politics and childhood in the twenty-first century, edited by S. Wagg and J. Pilcher. Basingstoke: Palgrave Macmillan.

Hall, SM. 2015. Everyday family experiences of the financial crisis: getting by in the recent economic recession. Journal of Economic Geography.

Hart, J. 2008. Children's Participation and International Development: Attending to the Political. The International Journal of Children's Rights 16 (3):407-418.

Hart, R. 1992. Children's Participation From Tokenism to Citizenship. Florence: UNICEF United Nations Childrens Fund.

Holloway, SL, and H Pimlott-Wilson. 2014. Enriching Children, Institutionalizing Childhood? Geographies of Play, Extracurricular Activities, and Parenting in England. Annals of the Association of American Geographers 104 (3):613-627.

James, A. 2007. Giving voice to children's voices: Practices and problems, pitfalls and potentials. American Anthropologist 109 (2):261-272.

Joint Public Issues Team. 2015. Time to rethink benefit sanctions [TtRBS]. city not provided: Methodist Publishing.

Kallio, KP, and J Häkli. 2011. Are There Politics in Childhood? Space and Polity 15 (1):21-34.

Larkins, C, J Lloyd, N Thomas, B Carter, N Farrelly, and D Judd. 2015. Support for Children's Protagonism. The International Journal of Children's Rights 23 (2):332-364.

Liebel, M. 2014. Adultism and age-based discrimination against children. In Children and nondiscrimination: Interdisciplinary textbook, edited by D. Kustar and H. Warming. Berlin: Children's Rights European Academic Network. 
McNally, D. 2010. Global Slump: The Economics and Politics of Crisis and Resistance. Oakland, CA: PM Press/Spectre.

Mohanty, CT. 2003. "Under Western eyes" revisited: Feminist solidarity through anticapitalist struggles. Signs: Journal of Women in Culture and Society 28 (2):499-535.

Nieuwenhuys, O. 2011. From Child Labour to Working Children's Movements. In The Palgrave Handbook of Childhood Studies, edited by J. Qvortrop, W. A. Corsaro and M.-S. Honig. Basingstoke, Hampshire: Palgrave Macmillan.

Nolas, S-M. 2015. Children's Participation, Childhood Publics and Social Change: A Review. Children \& Society 29 (2):157-167.

Olk, T. 2011. Children, generational relations and intergenerational justice. In The Palgrave Handbook of Childhood Studies, edited by J. Qvortrup, W. Corsaro and M.-S. Honig. Basingstoke, Hampshire: Palgrave Macmillan.

Oswell, D. 2009. Yet to come? Globality and the sound of an infant politics. Radical Politics Today 1 (1):1-18.

Qvortrup, J. 1995. From useful to useful: The historical continuity of children's constructive participation. In Sociological Studies of Children, edited by N. Mandell and A.-M. Ambert. Greenwich,CT: JAI Press.

Ridge, T. 2009. Living with poverty: a review of the literature on children's and families' experiences of poverty (research report 594). London: DWP.

Ridge, T. 2011. The Everyday Costs of Poverty in Childhood: A Review of Qualitative Research Exploring the Lives and Experiences of Low-Income Children in the UK. Children \& Society 25 (1):73-84.

Ridge, T. 2013. 'We are All in This Together'? The Hidden Costs of Poverty, Recession and Austerity Policies on Britain's Poorest Children. Children \& Society 27 (5):406-417.

Roets, G, R Roose, and M Bouverne-De Bie. 2013. Researching child poverty: Towards a lifeworld orientation. Childhood 20 (4):535-549.

Rosen, R. 2015. 'The Scream': Meanings and Excesses in Early Childhoods Settings. Childhood 22 (1):39-52.

Rosen, R, S Baustad, and M Edwards. in press. The crisis of social reproduction under global capitalism: Working class women and children in the struggle for universal childcare. In Caring for Children: Social Movements and Public Policy in Canada, edited by R. Langford, S. Prentice and P. Albanese. Vancouver: UBC Press.

Ruddick, S. 2007. At the Horizons of the Subject: Neo-liberalism, neo-conservatism and the rights of the child Part One: From 'knowing' fetus to 'confused' child. Gender, Place \& Culture 14 (5):513-527.

Scholz, SJ. 2015. Reconceptualizing Work and Building Ruddick's Feminist Solidarity Transnationally. Politics \& Gender 11 (02):382-405.

Siddiqi, DM. 2014. Solidarity, Sexuality, and Saving Muslim Women in Neoliberal Times. WSQ: Women's Studies Quarterly 42 (3-4):292-306.

Spyrou, S. 2011. The limits of children's voices: From authenticity to critical, reflexive representation. Childhood 18 (2):151-165.

Walker, J, K Crawford, and F Taylor. 2008. Listening to children: gaining a perspective of the experiences of poverty and social exclusion from children and young people of single-parent families. Health \& Social Care 16 (8).

Wells, K. 2009. Childhood in a Global Perspective. London: Polity.

Woodhead, M. 2011. Child development and development of childhood. In The Palgrave Handbook of Childhood Studies, edited by J. Qvortrup, W. Corsaro and M.-S. Honig. Basingstoke, Hampshire: Palgrave Macmillan.

Zelizer, V. 1994. Pricing the Priceless Child: The changing social value of children. Princeton, N.J. ; Chichester: Princeton University Press. 
